\title{
Meiotic Studies in Papaya (Carica papaya (L)) infected by Papaya Ring Spot Virus (PRSV).
}

\author{
*Ravindra Kumar Pandey \\ P.G.Department of Botany (Plant Pathology Lab) M.L.K.P.G.College, Balrampur (U.P.) 271201 \\ (Affiliated to Siddharth University, Kapilkvastu, Siddharth Nagar (U P) India \\ Corresponding Author: Ravindra Kumar Pandey
}

\section{Introduction}

Papaya (Carica papaya L.) is a tropical and subtropical crop widely cultivated for edible fruits. It is member of the small family Caricaceae .Papaya is one of the few rapidly growing and heavily yielding fruit trees. In the peninsular region it bears fruits throughout the year, while under north Indian conditions it is in fruiting for about four month beginning from January. Papaya trees are affected by some fungi from seedling to fruit, that reduces the viability of plant and fruit numbers and quality.

Except fungal diseases viral diseases also affect from foliar to fruiting stages (Leaf curl and ring spot diseases). Trees affected do not die immediately but their fruit bearing capacity is diminished. Plants infected by PRSV develop a range of symptoms including ringed spots on the fruit, for which the virus is named. Other symptoms in include mosaic coloration and chlorosis of the leaves, streaks on petioles and the upper part of the trunk, and shape distortion of young leaves. The plants grow more slowly and become stunted. Plant infected within a few months of planting usually do not produce mature fruit, but those infected later can produce a smaller yield of lower quality papaya.Some time yield loss upto 75-95\%[1][2]

The papaya is regarded as a fair source of iron and calcium; a good source of vitamins A, B and C and an excellent source of vitamin $\mathrm{C}$ (ascorbic acid). It is rich in vitamin $\mathrm{A}, \mathrm{B}, \mathrm{B}_{1}, \mathrm{~B}_{12}, \mathrm{C} \& \mathrm{D}$ ).

One of the major problems of this crop is its susceptibility to mosaic virus .Papaya (C. papaya $\mathrm{L}$.) is an important fruit crop whose reproductive knowledge is still incipient specially, the basic research that can contribute to its genetic breeding to develop a resistant variety against highly mutable pathogen . The present study deals with comparative study between healthy and diseased plants that shows deviations in different stages of microsporogenesis that leads to reduced quantity and quality of fruit yield.

\section{Methodology}

The papaya seedlings will be raised from the seed of different varieties of papaya taken from NBPGR New, Delhi. Seedlings were raised in earthen pods of 6 inch diameter filled with mixture of soil and farm yard manure $(1: 1 \mathrm{w} / \mathrm{w})$. The soil mixture will be sterilized before raising the plant in it. All the experiment will be conducted in a insect proof chamber under normal day light. The plants were grown in a greenhouse in the campus of Botany Department, M L.P.G.College Balrampur .Virus inoculum taken from virus maintained in the green house of the Botany Department by trituration of frozen leaves of papaya plants seedlings showing mosaic symptoms. Inoculation of leaves was carried out by rubbing with finger after their being dusted with carborandum as described by [3]. The two month old plant will be sap inoculated the plant showing typical diseased symptoms will be selected after 25 days of inoculation.

At flowering, male plants were identified and labelled for the study. To study the chromosome association, chiasma frequency and meiotic abnormalities, young flower buds of suitable sizes from both normal and viral infected plants were collected from 9.00 a.m. to $11.00 \mathrm{a}$ a.m. These were fixed in 1: 3 acetoalcohol to which a small amount of ferric acetate $(1 \mathrm{~g}$ in $500 \mathrm{ml}$ acetoalcohol $)$ was added imparting a straw colour. After 48 hours of fixation young flower buds were rinsed with distilled water and they were preserved in $70 \%$ ethanol and kept in a refrigerator till used. Temporary slides were prepared from suitable anthers with $2 \%$ acetocarmine by using smear technique[4] The techniques proposed by [5]and improved by [6]was applied to stain young anthers. To estimate the meiotic index (MI), ready-to-open flower buds were fixed in an ethanol solution with acetic acid (3:1); after 24 hours the solution was replaced by $70 \%$ ethanol and the buds were stored in the refrigerator. Slides were prepared by the squashing technique, by staining the squashed anthers in a $1 \%$ acetic carmine dye solution. Subsequently, the slides were observed under an optical microscope to count the number of 54 normal (tetrad) and abnormal post-meiotic products. Tetrads with four cells of the same size were 
considered normal and any deviation was considered abnormal (monads dyad, triads, and polyads). Four slides/bud per plant- were prepared and 500 cells per slide were counted. The meiotic index (MI) was estimated as the ratio of the total normal tetrads by the total post-meiotic products [6].Observations were made from both healthy as well as diseased plants. The number of monads, dyads, triads, tetrads and polyads were recorded for the meiotic index calculation.

$$
\% \mathrm{MI}=\frac{\text { Number of normal tetrads } \times 100}{\text { total of post-meiotic products counted }}
$$

The meiotic index considered in this study was the mean of ten randomly sampled slides.

\section{Results And Discussion}

Carica papaya $\mathrm{L}$ belong to Caricaceae family and have $2 \mathrm{n}=18$ chromosomes. No unpaired chromosomes were observed in Carica papaya. Thus, there is no evidence of sexual heteromorphic chromosomes.

The different meiotic stages were observed, paying particular attention to the prophase I stage and to possible irregularities. Any abnormalities such as lagging chromosomes, sticky chromosomes, and precocious segregation, among others, were registered.

The chromosome pairing studied in pollen mother cells (PMCs) at diakinesis in diseased and healthy plants at different intervals. Both diseased and healthy plant showed normal pairing of chromosome at pachytene with 9 bivalent $(2 \mathrm{n}=18)$, but different associations were observed at diakinesis in diseased and healthy plants at later stage of infection. In diseased plants multivalent configurations are more than healthy plants. Following configurations were observed in diseased and healthy plants.

In meiosis I and meiosis II laggard chromosome were observed chromosome bridges at anaphase I and II were also observed in both diseased and healthy plants but their percentage varied. Details of the findings are presented in table-1.

Table-1

Laggard chromosome (lag.) occurrence during meiosis I and II in diseased and healthy plants of Carica papaya. $\mathrm{U}=$ univalent $\mathrm{B}=$ bivalent $\mathrm{D}=$ disease, $\mathrm{H}=$ healthy.

\begin{tabular}{|c|c|c|c|c|c|c|c|c|c|c|}
\hline \multirow{2}{*}{$\begin{array}{c}\text { Meiotic } \\
\text { phases. }\end{array}$} & \multicolumn{2}{|c|}{ Cells without lag } & \multicolumn{2}{c|}{ Cells with lag-V } & \multicolumn{2}{c|}{ Cells with lab-B } & \multicolumn{2}{c|}{ Total cells analysed } & \multicolumn{2}{c|}{$\%$ of cells with lag } \\
\cline { 2 - 12 } & $\mathrm{D}$ & $\mathrm{H}$ & $\mathrm{D}$ & $\mathrm{H}$ & $\mathrm{D}$ & $\mathrm{H}$ & $\mathrm{D}$ & $\mathrm{H}$ & $\mathrm{D}$ & $\mathrm{H}$ \\
\hline Metaphase I & 140 & 160 & 14 & 10 & 5 & 4 & 159 & 174 & 11.94 & 8.04 \\
\hline Anaphase I & 210 & 195 & 18 & 14 & 4 & 4 & 232 & 213 & 9.48 & 8.45 \\
\hline Telophase I & 306 & 276 & 19 & 15 & 4 & 2 & 399 & 293 & 6.99 & 5.85 \\
\hline Metaphase II & 108 & 115 & 5 & 3 & 3 & 2 & 116 & 120 & 6.89 & 4.16 \\
\hline Anaphase II & 190 & 195 & 9 & 3 & 2 & 2 & 201 & 200 & 5.47 & 2.50 \\
\hline Telophase II & 210 & 161 & 4 & 2 & 1 & 0 & 215 & 163 & 2.32 & 1.22 \\
\hline
\end{tabular}

On average in meiosis I, laggard chromosome were found in $9.47 \%$ and $7.45 \%$ of diseased and healthy cells analyzed respectively, while in meiosis II, laggard chromosomes were found in $4.89 \%$ and $2.62 \%$ cells of disease and healthy cells respectively. Chromosome bridges were also found in anaphase I and II of diseased and healthy plants respectively. Lagging and eliminated chromosome at A-II formed micronuclei at T-II, being excluded from quartet of nuclei. Thus it can be concluded from above observation that laggard chromosomes are more in diseased plants than in healthy ones.

Table No-2 Post -meiotic products and meiotic index (M.I) in healthy plants of Carica papaya

\begin{tabular}{|c|c|c|c|c|c|c|c|}
\hline \multirow[t]{2}{*}{ Repetitions } & \multicolumn{5}{|c|}{ Products number resulting of meiosis-II } & \multirow{2}{*}{$\begin{array}{c}\text { Total of cell } \\
\text { analysed }\end{array}$} & \multirow{2}{*}{ M.I\% } \\
\hline & Monads & Dyads & Triads & Tetrads & Polyads & & \\
\hline 1. & 1 & 2 & 7 & 470 & - & 480 & 97.91 \\
\hline 2. & - & - & 6 & 315 & - & 321 & 98.13 \\
\hline 3. & 2 & 3 & 6 & 391 & 1 & 402 & 97.26 \\
\hline 4. & 1 & 2 & 8 & 484 & - & 495 & 97.77 \\
\hline 5. & - & 4 & 6 & 499 & - & 509 & 98.03 \\
\hline 6. & 1 & 3 & 5 & 260 & - & 269 & 96.65 \\
\hline 7. & - & 2 & 12 & 490 & - & 504 & 97.22 \\
\hline 8. & - & 1 & 9 & 501 & - & 511 & 98.04 \\
\hline 9. & 1 & 3 & 10 & 478 & 1 & 492 & 97.15 \\
\hline 10. & 1 & 1 & 9 & 507 & 1 & 518 & 97.87 \\
\hline Total & 7 & 21 & 78 & 4385 & 4 & 4501 & 97.42 \\
\hline
\end{tabular}

According to data in above table, the meiotic index mean was $97.42 \%$ but monads, dyads, triads and polyads were observed and quantity of triads was greater than the other irregularities. 
Meiotic Studies in Papaya (Carica papaya (L)) infected by Papaya Ring Spot Virus ( PRSV).

Table No.3 Post -meiotic products and meiotic index (M.I) in diseased plants of Carica papaya

\begin{tabular}{|c|c|c|c|c|c|c|c|}
\hline \multirow[t]{2}{*}{ Repetitions } & \multicolumn{5}{|c|}{ Products number resulting of meiosis-II } & \multirow{2}{*}{$\begin{array}{l}\text { Total of cell } \\
\text { analysed }\end{array}$} & \multirow{2}{*}{ M.I\% } \\
\hline & Monads & Dyads & Triads & Tetrads & Polyads & & \\
\hline 01. & - & 15 & 147 & 608 & 1 & 771 & 78.85 \\
\hline 02. & 1 & 19 & 169 & 597 & - & 786 & 75.95 \\
\hline 03. & 2 & 24 & 132 & 481 & 1 & 640 & 75.15 \\
\hline 04. & 3 & 18 & 298 & 742 & 1 & 1062 & 69.86 \\
\hline 05. & 2 & 30 & 126 & 480 & 2 & 640 & 75.0 \\
\hline 06. & 3 & 35 & 106 & 400 & - & 544 & 73.53 \\
\hline 07. & 1 & 20 & 084 & 306 & 2 & 413 & 74.09 \\
\hline 08. & 2 & 14 & 060 & 450 & - & 526 & 85.53 \\
\hline 09. & - & 17 & 078 & 342 & 1 & 438 & 78.08 \\
\hline 10. & 1 & 13 & 98 & 278 & 1 & 381 & 72.96 \\
\hline Total & 15 & 205 & 1298 & 4684 & 9 & 6201 & 75.54 \\
\hline
\end{tabular}

According to data in above table, the meiotic index mean was $75.54 \%$ but monads, dyads, triads and polyads was observed, and quantity of triads was greater than the other irregularities.

(Data given in tables 1, 2, 3 are statistically verified)

Chromosome association in normal and virus infected plants were studied from their pollen mother cells (PMCs) at diakinesis. But in case of virus infected plants species showed irregular chromosome association. In addition to bivalent, univalent were observed. The findings of the present study revealed that in normal plants, meiosis as well as bivalents formation were regular at diakinesis. On the other hand, in virus infected plants, asynapsis was noticed at diakinesis. The presence of univalent at diakinesis and M-I were reported by [7]. A complete breakdown of meiosis in plants infected with virus was reported in tobacco by [8] and in tomato by [9].

[10] Reported a significant reduction in chiasma frequency and partial asynapsis in chilies infected with mosaic virus. The chromosome fragments and micronuclei were not observed in any normal plants. The percentages of different meiotic abnormalities were found to vary among the normal and virus infected plants. The findings also indicated that lagging chromosomes were predominate than chromosome bridges. In virus infected plants anomalies like increased cell and chromosome size associated with fragmentation of chromosomes has been reported [11].

\section{Conclusion}

The deviations in meiotic studies specialy microsporogenesis leads to infertility of pollen due to deviations in meiotic and post meiotic behavior of cell division process,i.e.laggerd chromosome, deviations in meiotic index etc. The present investigation revealed a negative impact of virus infection on meiotic cell division of the Papaya plants showing irregular chromosome association in Meiosis I and II. The different types of abnormalities such as fragments, laggards and bridges were found in normal and diseased plants but lagging chromosomes were more common than chromosome bridges in virus infected plants. These chromosomal abnormalities during cell division leads to in viability of daughter cells that leads to pollen sterility.The study may help in establishing correlation between host and pathogen for understanding the basic principle of cytology.

\section{Acknowledgement}

Author is thankful to Principal M. L. K. P. G. College, Balrampur and Head Department of Botany for providing basic facilities to perform the present study.

\section{References}

[1] Khurana, S.M.P. (1968). Studies on virus disease of papaya (carica papaya L.) in Gorakhpur. Ph. D. thesis, Uni. Of Gorakhpur, India.

[2] Muniyappa, V. (2003) Plant disease Scenario in south India. Indian phytopato, 56:328.

[3] Rawlins, T.E. and Tompkins, C.M.(1936). Studies on the effect of carborandum as abrasive in plant virus inoculation. Phytopathology, 26:578. 66.

[4] Alexander M. P., 1969 - Diferential staining of aborted and nonaborted pollen. Stain Technology, 44:117-122.

[5] Belling. 1926. Iron acetocarmine method of fixing and staining chromosomes. Biology Bulletin 58: 355-363.

[6] Mc Lintok B. 1992. A method of making acetocarmine smears permanent. Strain Technology 4:53-60.

[7] Kaul, B.L. 1968. A study of meiosis in virus infected Datura quarcifolia. Cytologia 33: 17-20.

[8] Kostoff, D. 1933. Meiotic study in virus infected tobacco plants. Genetica 15: 103-114.

[9] Caldwell, J. 1952. Study of meiosis in virus infected tomato plants. Ann. Appl. Biol. 39: 98-102.

[10] Swaminathan, M.S., T. Ninan and M.L. Magoon. 1959. Cytological effects of mosaic virus in chillis.Genetica. 30: 63-69.

[11] Diaz, M. and C. Pavan. 1965. Chromosomal anomalies due to virus infection in different crop.plants. Proc. Natl. Acad. Sci. Wash. 54: 1321-1327. 
Meiotic Studies in Papaya (Carica papaya (L)) infected by Papaya Ring Spot Virus ( PRSV).

IOSR Journal of Biotechnology and Biochemistry (IOSR-JBB) is UGC approved Journal with S1. No. 4033, Journal no. 44202. 